\title{
Analisis Kinerja Keuangan pada PT. Bank Perkreditan Rakyat (BPR) Kabupaten Simalungun
}

\author{
Eka Pratiwi Septania Parapat ${ }^{1}$ \\ Sekolah Tinggi Akuntansi dan Manajemen \\ Indonesia \\ ekapsparapat@gmail.com
Benjamin Albert Simamora ${ }^{3}$
Politeknik Bisnis Indonesia
bjmmora@gmail.com

\author{
Kisno $^{2}$ \\ Sekolah Tinggi Akuntansi dan Manajemen \\ Indonesia \\ d.shinoda85@gmail.com \\ Amelia $^{4}$ \\ Sekolah Tinggi Akuntansi dan Manajemen \\ Indonesia \\ Amelia.ak@gmail.com
}

\begin{abstract}
ABSTRAK
The purpose of this study was to determine the financial condition based on liquidity ratio, colvency ratio, and profitability ratios in the PT. Bank Perkreditan Rakyat (BP R)KABUPATEN SIMALUNGUN Siantar in the years $2013-2015$. Field research method by approaching directly to the company that became the object of study. Book study library to research conducted by several scientific books and papers relating to discussion conducted. The total assets in 2013 was Rp. 20.405.837.239 and increased in 2014 to Rp. 21.845.491.637, and in 2015 also increased to at $R p$. 24.383.506.204. In 2013 the number of sales of Rp.3.527.453.681 the company makes a profit of Rp. 386.631.825. In 2014 sales increased nto as much Rp. 3.820.802.620 with profit Rp. 440.536.679 and also increased from the previous year. In 2015 the company sales increased much Rp. 4.127.157.198, and makes a profit of Rp. 504.013.708.
\end{abstract}

Keywords : Analysis, Performance, Finance.

\section{PENDAhuluan}

Perkembangan dunia saat ini dalam hal perbankan di Indonesia saat ini semakin kompetitif yang mana menuntut setiap perbankan untuk dapat mengolah dan melaksanakan manajemen perbankan menjadi lebih profesional.

Bank merupakan badan usaha yang tugas utamanya sebagai lembaga perantara keuangan (financial intermediaries), yang menyalurkan dana dari pihak yang berkelebihan dana kepada pihak yang membutuhkan dana atau kekurangan dana pada waktu yang ditentukan.

Kinerja keuangan bank dapat diukur dengan rasio likuiditas, rasio solvabilitas, dan rasio profitabilitas. Laporan keuangan merupakan suatu proses untuk membantu memecahkan dan sekaligus menjawab masalah- masalah yang timbul dalam suatu organisasi perusahaan maupun organisasi yang tidak bertujuan untuk memperoleh laba (Drs. Amin Widjaja 2000:22). Kinerja keuangan PT. Bank Perkreditan Rakyat ini untuk tahun 2013 sampai 2015 dapat diketahui melalui laporan keuangan yang berupa laporan neraca dan laporan rugi/laba pada tahun 2013 sampai 2015. Laporan keuangan tersebut selanjutnya dianalisa dengan menggunakan analisis rasio keuangan yaitu meliputi rasio likuiditas, rasio solvabilitas, dan rasio profitabilitas.

Berikut ini laporan laba rugi $P$ T. BPR KABUPATEN SIMALUNGUN untuk periode 2013 sampai dengan periode 2015 .

Tabel 1. Laporan Laba Rugi PT. BPR KABUPATEN SIMALUNGUN
\begin{tabular}{|l|c|r|r|}
\hline \multicolumn{1}{|c|}{ Tahun 2013-2015 (Rupiah) } \\
\hline Penjualangan & $\mathbf{2 0 1 3}$ & $\mathbf{2 0 1 4}$ & $\mathbf{2 0 1 5}$ \\
\hline & 3.527 .453 .681 & 3.820 .802 .620 & 4.127 .157 .198 \\
\hline Laba Bersih & 386.631 .825 & 440.536 .679 & 504.013 .708 \\
\hline
\end{tabular}
Sumber: Laporan Laba Rugi PT. BPR KABUPATEN SIMALUNGUN

Pada Tahun 2013 dengan jumlah penjualan sebesar Rp. 3.527.453.681 perusahaan memperoleh laba sebesar Rp. 386.631.825. Pada Tahun 2014 penjualan meningkat dari tahun sebelumnya, dimana jumlah penjualan adalah sebesar Rp. 3.820.802.620 sehingga laba yang diperoleh juga mengalami peningkatan dimana jumlah 
laba yang diperoleh pada Tahun 2014 adalah sebesar Rp. 440.536.679. Pada Tahun 2015 penjualan juga mengalami peningkatan hgi dari tahun sebelumnya adalah sebesar Rp. 4.127.157.198, dan laba yang dihasilkan juga mengalami penambahan dari tahun sebelumnya menjadi sebesar Rp. 504.013.708.

\section{Rumusan Masalah}

Berdasarkan latar belakang masalah di atas maka rumusan masalah dalam penelitian ini adalah bagaimana kondisi keuangan PT. Bank Perkreditan Rakyat KABUPATEN SIMALUNGUN Siantar serta perkembangan posisi keuangan P T. Bank Perkreditan Rakyat KABUPATEN SIMALUNGUN Siantar tiap tahunnya jika dilakukan perbandingan?

\section{STUDI LITERATUR}

\section{Bank Perkreditan Rakyat (BPR)}

Bank Perkreditan Rakyat (BPR) yaitu bank yang melaksanakan kegiatan usaha secara konvensional atau berdasarkan prinsip syariah, tetapi tidak memberikan jasa dalam lalu lintas pembayaran.

\section{Lembaga Keuangan}

Menurut UU RI pasal 1 ayat 2 No. 10 tahun 1998 tentang perbankan mendefinisikan bahwa "Bank adalah badan usaha yang menghimpun dana dari masyarakat dalam bentuk simpanan dan menyalurkannya kepada masyarakat dalam bentuk kredit dan atau bentuk - bentuk lainnya dalam rangka meningkatkan taraf hidup rakyat banyak".

\section{Kinerja Keuangan}

Kinerja keuangan perusahaan menurut Munawir: 2000, merupakan suatu gambaran tentang kondisi keuangan suatu perusahaan yang dianalisis dengan alat-alat analisis keuangan, sehingga dapat diketahui mengenai baik buruknya keadaan keuangan suatu perusahaan yang mencerminkan prestasi kerja dalam periode tertentu.

\section{Laporan Keuangan}

1) Pengertian Laporan Keuangan keuangan adalah pokok atau hasil akhir dari suatu proses akuntansi yang menjadi bahan informasi bagi para pemakainya sebagai salah satu bahan dalam proses pengambilan keputusan dan juga dapat menggambarkan indikator kesuksesan suatu perusahaan mencapai tujuannya".

2) Pihak-yang Memperoleh Laporan Keuangan

Menurut Drs. Amin Widjaja (2000:23) pihakpihak yang membutuhkan laporan keuangan adalah sebagai berikut:
a. Pimpinan Perusahaan
b. Kreditur
c. Penanaman Modal (Investor)
d. Pemerintah
e. Karyawan
f. Akuntan Publik

3) Jenis Laporan Keuangan

Menurut Harahap (2010:106) jenis Laporan keuangan terdiri dari beberapa komponen komponen sebagai berikut:

a. Daftar Neraca yang menggambarkan posisi keuangan perusahaan pada suatu tanggal tertentu

b. Perhitungan laba / rugi yang menggambarkan jumlah hasil, biaya dan laba/rugi perusahaan pada suatu periode tertentu.

c. Laporan sumber dan penggunaan dana

d. Laporan arus kas

\section{Rasio Keuangan}

Kinerja keuangan bank dapat diukur dengan menggunakan rasio keuangan, antara bin: rasio likuid itas rasio solvabilitas, dan rasio profitabilitas.

\section{Rasio Likuiditas}

Yaitu menggambarkan kemampuan perusahaan untuk menyelesa ikan kewajiban jangka pendeknya.

\section{Rasio Solvabilitas}

Yaitu menggambarkan kemampuan perusahaan dalam membayar kewajiban jangka panjang maupun kewajibankewajibannya yang apabila perusahaan dilikuidasi.

\section{Rasio Profitabilitas}

Adalah rasio yang menunjukkan kemampuan perusahaan untuk memperoleh keuntungan dari pengunaan modalnya.

Teori pengaruh net profit margin terhadap harga saham Menurut Harahap (2015 : 304) " Profit margin menunjukkan berapa besar presentase pendapatan bersih yang diperoleh dari setiap penjualan. Semakin besar rasio ini 
semakin baik karena dianggap kemampuan perusahaan dalam mendaptkan laba cukup tinggi. Hal ini tentunya akan menarik minat investor untuk berinvestasi sehingga menaikkan harga saham.

\begin{tabular}{|c|c|c|c|}
\hline \multicolumn{4}{|c|}{$\begin{array}{c}\text { Tabel } 2 \\
\end{array}$} \\
\hline \multirow[b]{2}{*}{ Rasio Keuangan } & \multicolumn{2}{|c|}{ Rata-Rata Industri } & \multirow[b]{2}{*}{ Kategori } \\
\hline & Angka & Persentase & \\
\hline $\begin{array}{l}\text { 1. Rasio Likuiditas } \\
\text { Current Ratio } \\
\text { Cash Ratio }\end{array}$ & & $\begin{array}{l}200 \% \\
30 \%\end{array}$ & $\begin{array}{l}\text { Baik } \\
\text { Bakk }\end{array}$ \\
\hline 2. $\quad$ Rasio Solvabilitas & & & \\
\hline Debt Ratio & & $35 \%$ & Baik \\
\hline Debt Equity Ratio & & $90 \%$ & Bak \\
\hline 3. Rasio Profitabilitas & & & \\
\hline Gross Profit Margin & & $30 \%$ & Baik \\
\hline Net Profit Margin & & $10 \%$ & Bakk \\
\hline Return On Investment & & $30 \%$ & Baik \\
\hline Return On Equity & & $5 \%$ & Baik \\
\hline Return On Asset & & $0,5 \%$ & Baik \\
\hline
\end{tabular}

Sumber: BEI

\section{METODOLOGI PENELITIAN}

Metode Pengumpulan data

a. Penelitian Lapangan (Field Research) Yaitu suatu metode penelitian dengan cara mendatangi langsung ke perusahaan yang menjadi objek kajian.

b. Studi Pustaka (Library Research) Yaitu penelitian yang dilakukan ke perpustakaan dengan beberapa bukubuku ilmiah dan tulisan-tulisan yang berhubungan dengan pembahasan yang dilakukan.

\section{Metode Analisa Data}

Dalam menganalisa data, penulis menggunakan analisa data kuantitatif sebagai metode penelitian yang menjelaskan secara deskriptif mengenai analisa rasio terhadap laporan keuangan PT. Bank Perkreditan Rakyat KABUPATEN SIMALUNGUN Siantar untuk periode 2013 sampai 2015.

\section{Hasil dan pembahasan}

1. Analisis Rasio Likuiditas

a. Current Ratio

Rasio ini menunjukkan nilai kekayaan lancar (segera dapat dijadikan uang) yang dimiliki oleh perusahaan.

b. Cash Ratio. Rasio ini adalah rasio yang paling konservatif untuk mengukur kemampuan perusahaan untuk memenuhi kewajiban lancarnya dengan menggunakan aktiva-aktiva kas dan atau setara kas.

\section{Analisis Rasio Solvabilitas}

a. Debt Ratio (Rasio Hutang) Merupakan rasio yang mengukur berapa persen aset perusahaan yang dibelanjai dengan hutang.

b. Total Debt to Equity Ratio Merupakan perbandingan dari total hutang yang dimiliki perusahaan dengan modal sendiri (ekuitas). Artinya bagian dari setiap rupiah modal sendiri yang dijadikan jaminan untuk keseluruhan hutang perusahaan.

\section{Analisis Rasio Profitabilitas}

a. Rasio Margin Laba Kotor (Gross Profit Margin) Rasio ini digunakan untuk menggambarkan kemampuan perusahaan dalam mendapatkan laba atau deviden

b. Rasio Margin Laba Bersih (Gross Net Profit) keuntungan bersih yang diperoleh ole perusahaan selama periode tertentu (tahun buku) dari setiap rupiah penjualan.

c. Return On Investment (Rasio Pengembalian Atas Aktiva) Rasio ini mengukur pengembalian atas total aktiva setelah bunga dan pajak.

d. Return On Equity (ROE) Digunakan untuk mengukur banyaknya keuntungan yang menjadi hak pemilik modal sendiri.

e. Return On Assets (ROA) untuk mengukur kemampuan perusahaan dalam memperoleh laba perusahaan dengan aktiva yang digunakan untuk memperoleh laba tersebut. ROA dihitung dengan membagi laba usaha (EBIT) dengan total aktiva.

\section{Pembahasan}

\section{Rasio Likuiditas}

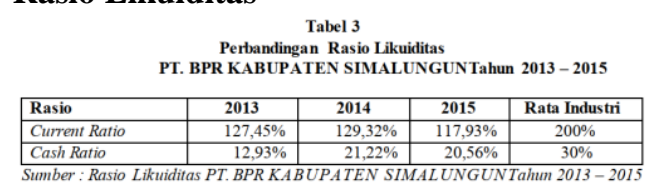

Rasio Solvabilitas

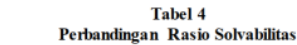

Perbandingan Rasio Solvabilitas
PT. BPRKABUPATEN SIMUALUNGUNTah 2013- 2015

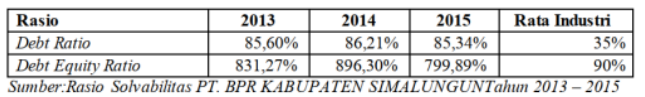

Rasio Profitabilitas 
Tabel 5
Perbandingan Rasio Profitabilitas PT. BPR KABUPATEN SIMALUNGUN

\begin{tabular}{|c|c|c|c|c|}
\hline Rasio & 2013 & 2014 & 2015 & $\begin{array}{c}\text { Rata } \\
\text { Industri }\end{array}$ \\
\hline Gross Profit Margin & $12,51 \%$ & $12,52 \%$ & $13,21 \%$ & $30 \%$ \\
\hline Net Profith 1 & $10,96 \%$ & $11,52 \%$ & $12,21 \%$ & \\
\hline Return On 1 & $1,89 \%$ & $2,01 \%$ & $2,06 \%$ & $30^{\circ}$ \\
\hline Return On Eq & $18,39 \%$ & $20,96 \%$ & $19,37 \%$ & \\
\hline Return On Asset & $2,16 \%$ & $2,19 \%$ & $2,23 \%$ & $0,5^{\circ}$ \\
\hline
\end{tabular}

V. KESIMPULAN DAN SARAN

Kesimpulan

Berdasarkan analisa laporan keuangan dengan menggunakan rasio likuiditas, solvabilitas, dan profitabilitas dalam menilai kinerja keuangan pada PT. BP $R$ KABUPATEN SIMALUNGUN dari Tahun 2013 sampai dengan 2015, dapat ditarik kesimpulan yaitu tingkat likuiditas pada Tahun 2013 sampai dengan 2015 terlihat kurang efisien atau kurang baik. Tingkat solvabilitas perusahaan pada Tahun 2013 sampai dengan 2015 terlihat sangat baik. Walaupun disana terlihat bahwa setiap tahun terjadi penurunan dan peningkatan, baik dari segi debt ratio maupun debt equity ratio. Dari tingkat rasio profitabilitas

\section{Saran}

Berdasarkan masalah yang dihadapi dalam perhitungan kinerja perusahaan, maka saran yang diberikan yaitu untuk rasio profitabilitas pada PT. BPR KABUPATEN SIMALUNGUN harus lebih mengembangkan produk dan kualitas pelayanan jasa nya, agar untuk ratio profitabilitasnya meningkat dari tahun ketahun, dan bisa menjadi lembaga perbankan yang dipercaya oleh masyarakat setempat, serta mampu berkontribusi di dunia perbankan.

\section{Daftar Pustaka}

Drs.Amin Widjaja Tunggal Ak.MBA, 2000, Dasar-Dasar Analisis Laporan Keuangan PT Rineka Cipta, Jakarta.

Ketetapan UU RI Pasal 1 ayat 2 No.10 Tahun 1998 Tentang Perbankan, Jakarta.

Munawir S, 2000, Analisa Laporan Keuangan, Yogyakarta: Liberty.

Munawir S, 2004, Analisa Laporan Keuangan, Yogyakarta: Liberty.

Harahap Sofyan S yafri, 2004, Analisis Kritis Atas Laporan Keuangan, Jakarta: Rajawali

Harahap Sofyan Syafri, 2010, Analisis Kritis Atas Laporan Keuangan, Jakarta: Rajawali.

Kasmir, 2008, Analisis Laporan Keuangan, Jakarta: Rajawali Pers.

Sutojo Siswanto F.K leinsteuber, 2004, Manajemen Keuangan Bagi Eksekutif Non-Keuangan, Damar Mulia Pustaka, Jakarta. 